\title{
Genesis or Genocide? Leonard Wood, Theodore Roosevelt and the White Man's Empire in the Southern Philippines
}

\author{
Omar H. Dphrepaulezz ${ }^{1}$
}

This artcle examines the transformation of white masculinity in the United States from the 1870s to 1906 through the analytical prisms of the friendship between Theodore Roosevelt and Leonard Wood and their participation in the massacre at Bud Dajo in 1906. On March 5, 1906 United States Army units under the command of Wood attacked a band of Filipino Muslims, Tausug Moros, who had taken refuge on Bud Dajo, a volcanic summit on Jolo Island in the Sulu archipelago of the southern Philippines. The operation culminated in the massacre of approximately six hundred to one thousand men, women, and children. President Theodore Roosevelt and General Leonard Wood were not only principal players in this act of genocidal destruction, but also very close friends and proponents of a new brand of white masculinity for a new century and a vigorous overseas American empire. They saw in this expansionist project a new frontier for white men to test their mettle against savage and barbarous races. [Article copies available for a fee from The Transformative Studies Institute. E-mail address: journal@transformativestudies.org Website: http://www.transformativestudies.org (C2016 by The Transformative Studies Institute. All rights reserved.]

KEYWORDS: Apache, Cuba, Expansion, Masculinity, Tausug.

\footnotetext{
${ }^{1}$ Omar H. Dphrepaulezz, Ph.D., is a Historian of African American History, U.S. History, and U.S. Foreign Policy. He holds a dual appointment in the History Department, and the Africana and Latino Studies Department at SUNY Oneonta. He completed his Ph.D. in History at the University of Connecticut in 2013. His substantive areas of interest include the history of Islam in the African American community, race and immigration, race and crime, and the interface among race, gender, and U.S. empire. Dr. Dphrepaulezz has research and teaching experience in the History of American Foreign Relations, African-American History, U.S. History, and World History from 1500 to the Present. Address correspondence to: Omar H. Dphrepaulezz, SUNY Oneonta, Departments of African and Latino Studies and History, 287 Fitzelle Hall, Oneonta, NY 13820; e-mail: ohassan5@yahoo.com.
} 